\title{
CLUSTERING OF HIGH-TECH INDUSTRIAL PRODUCTION: FACTORS AND TRENDS
}

\author{
Dmitry Napolskikh \\ Volga State University of Technology, Russian Federation
}

The purpose of the study is to identify trends and future models for the development of regional industrial clusters in the new technological order. Paper deals with the dynamics of the formation of industrial clusters, the main regularities of the development of high-tech industries are revealed. Particular attention is given to localization of high-tech industries within the framework of regional industrial clusters; scientific novelty contains a model of inter-sectoral interaction in the conditions of the innovation economy. The result of the analysis shows, that successful cluster initiatives combine a developed innovative core, an essential industrial basis and a significant number of small and medium-sized forms of innovative entrepreneurship.

Key words: High-tech production, Industrial clusters, Inter-sectoral interaction, Production localization, Clustering models

\section{INTRODUCTION}

Insufficient level of demand for innovation from industrial production limits the potential for technological growth and the regulatory capabilities of state in the economy. State authorities play role of the locomotive for the development of high-tech industries and the coordinator of their clustering processes [12]. At the same time, particular attention is given to cooperation between universities and business, creation of innovative infrastructure and technological platforms, innovative development of companies with state participation. The support of regional industrial clusters is an effective and economically justified direction for supporting innovation activity [06]. Enterprises of such clusters are the largest exporters of high-tech products and significantly increase the competitiveness of the national economy in the world market [01].

In modern conditions the formation and development of industrial clusters remains the main direction of increasing the competitiveness of developing economies. The development of the cluster concept, as a rule, is linked with the work of M. Porter. M. Porter justifies the need for industrial specialization, carried out in accordance with historical assumptions in contrast to the prevailing at that time in the US development goals, which consist in supporting a diversified economy [14]. M. Dunford notes the role of organizational structures of the cluster, neoclassical transaction costs, non-commercial interdependence, organizational and managerial networks [05]. According to E. Bergman and E. Fether "cooperative competition» is typical for small and medium-sized enterprises in the cluster as a means of counteracting the pressure exerted by large companies using the advantages of internal economies of scale [03]. B. Arthur showed that the sectoral orientation of the cluster depends on the previous history of technological development and the sequence of previously adopted state decisions [02].

\section{DATA AND METHOD}

Methodological approach of the study focuses on the basic organizational model of cluster (Sölvell) [18], the model of cluster and regional specialization (Feser) [07], the institutional model of the cluster (Ketels, Lindqvist and Sölvell) [10]. The model of clustering of the economic space realizes the dialectic law of denying negation: the policy of cluster development comes to replace the previous concept of territorial production complexes, but in practice, it uses the industrial and infrastructural basis established within it [09]. This denial of negation forms an institutional synthesis, which is one of the conceptual foundations of the model for the formation of regional industrial clusters, developing on the basis of a conglomerate of territorial production complexes [11].

Based on data from the Federal Service for State Statistics of the Russian Federation [15], there was an analysis of the industry's localization of production in Russia. Analysis of the relationship between industry specialization and the formation of industrial clusters was carried out for high-tech industrial production [17]. Author considers industrial clusters within the framework of the model of inter-sectoral integration of the three echelons of clusters presented in Table 1.

As a criterion of specialization of the regional economic system in certain types of economic activity, it is proposed to use the localization coefficient of production (LC). Given that unlike territorial production complexes, clusters are characterized by both localization of production and its organizational deconcentration, the use of the Herfindahl-Hirschman Index $(\mathrm{HHI})$, traditionally used to assess the degree of monopolization of production within a certain industry, is justified. For identifying the objective prerequisites for the formation of regional clusters deserves the coefficient of concentration of economic activity - «concentration ratio» $(\mathrm{CR})$, which is

* Volga State University of Technology, 424000, the Republic of Mari El, Yoshkar-Ola, pl. Lenina 3, Russian Federation, 
calculated as the sum of market shares of three (four) largest economic agents of the territory. Use of the indicators discussed above is not self-sufficient and the only approach for making managerial decisions on supporting cluster initiatives at the regional level. The technique proposed by the author supplements existing approaches to assessing the effectiveness of cluster development, which also requires a detailed analysis of the specific socio-economic development of a particular territory. The advantage of using these indicators is the possibility of cluster development models in order to select the optimal strategy for clustering the economy for each particular territory, as well as differentiation of clusters from territorial production complexes and quasi-clusters.

In the framework of the methodology of geostatistical analysis, the study of clustering processes is based on the allocation of a certain territory on which a number of measurements of a certain economic value $Z$ are carried out. The spatial arrangement of the cluster participants causes an arbitrary character of the distribution over the region of the set of points at which the economic value $Z$ was measured. Accordingly, Clustering the economic space of Russian regions is called randomly distributed minutes on the territory of dots $(x, y)$, which measured the performance values of the cluster. The Delaunay triangulation allows qualitatively isolating the segments of the analyzed space with a high density of measurements, also called "clusters" in geostatistics. From the point of view of the instrumentation of applied research, Delaunay's triangulation is the basis for constructing linear interpolation: the three vertices of triangles uniquely determine the plane within which the quantitative values of the function under consideration are calculated according to geometric principles. Figure 1 shows the Delaunay triangulation and Voronoi polygons for the monitoring network of organizations participating in clusters of the Tatarstan Republic, there are two distinct centers of clustering processes in the cities of Kazan and Naberezhnye Chelny.

Table 1: Directions of inter-sectoral integration of the three echelons of clusters

\begin{tabular}{|c|c|c|}
\hline $\begin{array}{c}\text { Innovative clusters that develop } \\
\text { breakthrough technologies of the } \\
\text { next technological order }\end{array}$ & $\begin{array}{c}\text { Clusters of innovative } \\
\text { technologies and means of } \\
\text { production that initiate } \\
\text { multiplicative effects }\end{array}$ & $\begin{array}{c}\text { Clusters of high-tech products, } \\
\text { massively replicating innovative } \\
\text { technologies }\end{array}$ \\
\hline $\begin{array}{c}\text { Clusters of new composite and } \\
\text { polymeric materials }\end{array}$ & $\begin{array}{c}\text { Clusters of additive technologies } \\
\text { and digital modeling tools }\end{array}$ & $\begin{array}{c}\text { Clusters of heavy and medium } \\
\text { engineering }\end{array}$ \\
\hline $\begin{array}{c}\text { Clusters of sensorics and } \\
\text { mebiotics }\end{array}$ & Cluster of robotics & Clusters of precision engineering \\
\hline $\begin{array}{c}\text { Clusters of quantum } \\
\text { communication and cryptography }\end{array}$ & $\begin{array}{c}\text { Clusters of new communication } \\
\text { technologies }\end{array}$ & Clusters of personal security systems \\
\hline $\begin{array}{c}\text { Clusters of new and portable } \\
\text { energy sources }\end{array}$ & $\begin{array}{c}\text { Clusters of distributed energy } \\
\text { technologies }\end{array}$ & $\begin{array}{c}\text { Clusters of energy-efficient lighting } \\
\text { equipment }\end{array}$ \\
\hline $\begin{array}{c}\text { Clusters of genomics and } \\
\text { synthetic biology }\end{array}$ & $\begin{array}{c}\text { Clusters of biopharmaceutical } \\
\text { technologies and biomedicine }\end{array}$ & Clusters of personal medicine \\
\hline $\begin{array}{c}\text { Clusters of nuclear physics } \\
\text { research }\end{array}$ & Clusters of radiation technologies & Clusters of nuclear engineering \\
\hline Nanotechnology clusters & Radioelectronic clusters & $\begin{array}{c}\text { Clusters of microelectronics and } \\
\text { instrument engineering }\end{array}$ \\
\hline Photonics clusters & $\begin{array}{c}\text { Clusters of laser and fiber optic } \\
\text { technologies }\end{array}$ & $\begin{array}{c}\text { Clusters of industrial and medical } \\
\text { equipment }\end{array}$ \\
\hline Clusters of neurotechnologies & $\begin{array}{c}\text { Clusters of technologies of virtual } \\
\text { and augmented realities }\end{array}$ & $\begin{array}{c}\text { Clusters of artificial components of } \\
\text { consciousness and psyche }\end{array}$ \\
\hline
\end{tabular}




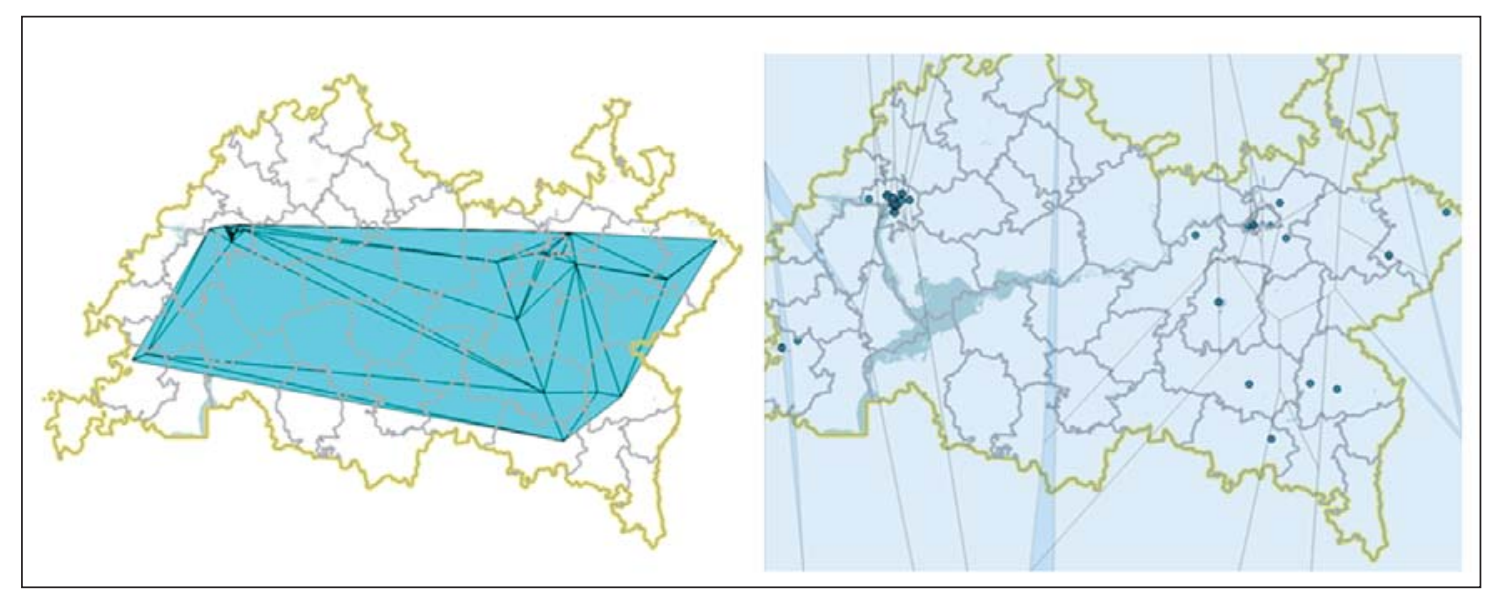

Figure 1: Delaunay triangulation and Voronoi polygons for the monitoring network of organizations participating in clusters of the Tatarstan Republic

\section{RESEARCH RESULTS}

Dynamics of cluster formation in the regions of the Russian Federation is shown in Table 2.

Accordingly, three "waves of clusterization" of the economic space of the Russian regions are singled out the first - 2009-2011, the second - 2011-2013, the third 2013-2016. Accordingly, the key task of the study is the development and parametrization of the organizational cluster development, which can become a factor in the generation of the "fourth wave" of clustering Russian regions. At the same time, the insufficient implementation of cluster policy instruments in the development of strategies and programs for regional development impedes the optimal use of the potential of innovative infrastructure facilities. The solution of the problems of economic development and modernization of the old industrial economic systems of the Russian regions actualizes the task of practical implementation of the model of perspective development of cluster initiatives within the framework of the innovation economy.

Tendencies and prospective models for the formation of regional industrial clusters in the Russian Federation are examined on the example of the economic systems of the regions in which clusters are formed, the key specialization of which are the information technologies, microelectronics, instrumentation, optics and photonics. Table 3 presents the characteristics of these clusters.

From the list of enlarged types of economic activity and industrial production sectors were chosen that should influence the formation and development of clusters of microelectronics, instrumentation and information technologies. From the list of enlarged types of economic activity and industrial production were chosen the ones that influence on the formation and development of clusters of microelectronics, instrumentation and information technologies of clusters. The values of the localization coefficient for these enlarged types of economic activity are presented in Table 4.
Low values of the localization coefficient of manufacture of electrical, electronic, optical equipment for the regions examined due to the following factors:

- orientation of information technology clusters in the Novgorod and Vologda regions to innovation and technological support for the formation of forest industrial clusters;

- orientation of the cluster of high-tech components and systems of the Omsk region to manufacturing industries in general;

- orientation of the information technology cluster of the Republic of Tatarstan to high-tech production in general, in particular: the production of machinery, vehicles and equipment, petrochemical production, etc.

\section{DISCUSSION}

Regional industrial clusters are characterized by significant concentration of high-tech enterprises, high dynamics of growth in production volumes, the availability of research and educational organizations. In general, the analyzed clusters are located in areas with a high concentration of scientific, technical and production activities [08]. These include science cities and special economic zones, in particular the cities of Zelenograd, Dubna, Pushchino, Obninsk, Troitsk, Sarov, Zheleznogorsk, Dimitrovgrad. Industrial clusters are also located on the territory of large urban agglomerations of St. Petersburg, Novosibirsk, Nizhny Novgorod, and Samara.

From the point of view of the territorial organization of industrial production, two models of cluster development can be distinguished:

1. localization of the cluster in clearly delineated territorial boundaries, almost coinciding with the boundaries of municipalities (Sarov, Zheleznogorsk, Troitsk);

2. localization within the network structures of large agglomerations (St. Petersburg, Novosibirsk and Tomsk regions) [13]. 
Table 2: Dynamics of clusters formation in the Russian Federation

\begin{tabular}{|c|c|c|c|}
\hline Years & $\begin{array}{c}\text { Number of created } \\
\text { clusters (units) }\end{array}$ & $\begin{array}{c}\text { Number of participating organizations } \\
\text { in 2016 for clusters created in the } \\
\text { corresponding period (units) }\end{array}$ & $\begin{array}{c}\text { Number of employees in 2016 for } \\
\text { clusters established in the } \\
\text { corresponding period (people) }\end{array}$ \\
\hline $1999-2007$ & 1 & 66 & 20838 \\
\hline 2008 & 1 & 11 & 2532 \\
\hline 2009 & 4 & 125 & 35130 \\
\hline 2010 & 7 & 178 & 68955 \\
\hline 2011 & 4 & 48 & 33175 \\
\hline 2012 & 19 & 970 & 558553 \\
\hline 2013 & 11 & 295 & 129407 \\
\hline 2014 & 27 & 656 & 231661 \\
\hline 2015 & 23 & 599 & 161488 \\
\hline 2016 & 4 & 71 & 25925 \\
\hline Total & 101 & 3019 & 1267664 \\
\hline
\end{tabular}

Table 3: Organizational aspects of formation of clusters of microelectronics, instrument engineering and information technologies

\begin{tabular}{|c|c|c|c|c|}
\hline Cluster & Region & $\mathrm{HHI}$ & $\mathrm{CR}_{3}$ & $\mathrm{CR}_{4}$ \\
\hline Radioelectronic cluster of the Voronezh region & \multirow{2}{*}{ Voronezh region } & 1721 & 0,61 & 0,69 \\
\hline Cluster "Voronezh Electromechanics" & & 1828 & 0,63 & 0,75 \\
\hline Information Technology Cluster & \multirow[b]{2}{*}{ Perm Region } & 2094 & 0,73 & 0,82 \\
\hline $\begin{array}{l}\text { Innovative territorial cluster of fiber-optic technologies } \\
\text { "Photonics" }\end{array}$ & & 1384 & 0,54 & 0,70 \\
\hline Cluster of integration of technologies «Zarechensky» & \multirow{2}{*}{ Penza region } & 2981 & 0,78 & 0,89 \\
\hline «Penza Instrument-Making Cluster "Security" & & 1709 & 0,63 & 0,73 \\
\hline The innovation-technological cluster "Southern constellation" & \multirow{3}{*}{ Rostov region } & 2603 & 0,84 & 0,90 \\
\hline $\begin{array}{l}\text { Innovative territorial cluster of civil marine } \\
\text { instrumentation "Marine Systems" }\end{array}$ & & 3302 & 0,89 & 0,93 \\
\hline $\begin{array}{l}\text { Cluster of information and communication } \\
\text { technologies of the Rostov Region }\end{array}$ & & 1734 & 0,61 & 0,77 \\
\hline Innovative territorial cluster "Zelenograd" & Moscow & 1064 & 0,53 & 0,60 \\
\hline $\begin{array}{l}\text { Cluster of high-tech components and systems } \\
\text { of Omsk region }\end{array}$ & Omsk Region & 1452 & 0,58 & 0,68 \\
\hline $\begin{array}{c}\text { The Scientific and Industrial Cluster of Instrument Making and } \\
\text { Electronics of the Oryol Region }\end{array}$ & Oryol Region & 1666 & 0,61 & 0,74 \\
\hline $\begin{array}{l}\text { Cluster of information technologies, radioelectronic } \\
\text { and telecommunications }\end{array}$ & St.Petersburg & 283 & 0,21 & 0,25 \\
\hline $\begin{array}{l}\text { Energy-efficient lighting technology and intelligent lighting } \\
\text { control systems }\end{array}$ & Republic of Mordovia & 1637 & 0,64 & 0,74 \\
\hline $\begin{array}{c}\text { Innovative cluster of information and biopharmaceutical } \\
\text { technologies }\end{array}$ & Novosibirsk region & 1034 & 0,47 & 0,54 \\
\hline Cluster of Information Technologies of the Vologda Region & Vologda Region & 1636 & 0,62 & 0,70 \\
\hline Cluster of Information Technologies of Novgorod Region & Novgorod region & 6497 & 0,87 & 0,88 \\
\hline Information Technologies cluster of the Republic of Tatarstan & Republic of Tatarstan & 4103 & 0,74 & 0,76 \\
\hline
\end{tabular}


Table 4: The values of the localization coefficient of enlarged types of economic activity and industrial production in the regions of the Russian Federation

\begin{tabular}{|c|c|c|c|c|c|c|}
\hline Region & $\begin{array}{c}\text { Agriculture } \\
\text { and forestry }\end{array}$ & $\begin{array}{c}\text { Manufacturing } \\
\text { plants as a } \\
\text { whole }\end{array}$ & $\begin{array}{c}\text { Food } \\
\text { production }\end{array}$ & Woodworking & $\begin{array}{c}\text { Machinery, } \\
\text { vehicles and } \\
\text { equipment }\end{array}$ & $\begin{array}{c}\text { Manufacture of } \\
\text { electrical, } \\
\text { electronic, } \\
\text { optical equipment }\end{array}$ \\
\hline Penza region & 2,43 & 1,21 & 2,37 & 1,31 & 0,93 & 2,47 \\
\hline $\begin{array}{c}\text { Novosibirsk } \\
\text { region }\end{array}$ & 1,24 & 0,74 & 1,95 & 0,92 & 1,1 & 2,02 \\
\hline Rostov region & 2,5 & 1,01 & 1,49 & 0,15 & 1,52 & 0,68 \\
\hline Moscow & 0,45 & 1,16 & 1,67 & 1,46 & 1,1 & 1,11 \\
\hline St.Petersburg & 1,33 & 1,39 & 1,69 & 2 & 1,77 & 1,72 \\
\hline Omsk Region & 1,98 & 2,09 & 0,64 & 0,15 & 0,15 & 0,54 \\
\hline Voronezh region & 3,17 & 0,78 & 2,47 & 0,15 & 0,95 & 2,3 \\
\hline Perm Region & 0,62 & 1,74 & 0,33 & 1,08 & 0,78 & 0,91 \\
\hline Vologda Region & 0,95 & 1,9 & 0,51 & 4,08 & 0,34 & 0,07 \\
\hline Novgorod region & 1,55 & 1,94 & 1,52 & 6,77 & 0,52 & 0,75 \\
\hline $\begin{array}{c}\text { Republic } \\
\text { of Tatarstan }\end{array}$ & 1,21 & 1,04 & 0,65 & 0,38 & 1,54 & 0,7 \\
\hline Oryol Region & 3,31 & 1,05 & 2,47 & 0,23 & 1,19 & 1,67 \\
\hline $\begin{array}{c}\text { Republic } \\
\text { of Mordovia }\end{array}$ & 2,45 & 1,29 & 2,52 & 1,15 & 0,61 & 3,09 \\
\hline
\end{tabular}

Table 5: Models of organizational development of clusters of microelectronics, instrumentation and information technologies

\begin{tabular}{|c|c|c|c|}
\hline \multirow{2}{*}{$\begin{array}{l}\text { Number of } \\
\text { participating } \\
\text { organizations } \\
\text { (units) }\end{array}$} & \multicolumn{3}{|c|}{$\begin{array}{l}\text { Values of the Herfindahl-Hirschman Index }(\mathrm{HHI}) \text { and the Coefficient of Concentration } \\
\qquad(\mathrm{CR} 3, \mathrm{CR} 4)\end{array}$} \\
\hline & $\begin{array}{l}\mathrm{HHI}>1800 \\
\mathrm{CR} 3<0,90 \\
\mathrm{CR} 4<0,95\end{array}$ & $\begin{array}{l}\mathrm{HHI}<1800 \\
\mathrm{CR} 3<0,60 \\
\mathrm{CR} 4<0,75\end{array}$ & $\begin{array}{l}\mathrm{HHI}<1000 \\
\mathrm{CR} 3<0,50 \\
\mathrm{CR} 4<0,60\end{array}$ \\
\hline From 10 to 25 & $\begin{array}{l}\text { Cluster formed on the basis of } \\
\text { territorial production complex. } \\
\text { Priority: development of small } \\
\text { and medium-sized innovative } \\
\text { entrepreneurship }\end{array}$ & $\begin{array}{l}\text { Cluster with a clearly } \\
\text { defined core. } \\
\text { Priority: development of } \\
\text { small and medium-sized } \\
\text { innovative entrepreneurship }\end{array}$ & $\begin{array}{l}\text { Cluster with a developed } \\
\text { competitive environment. } \\
\text { Priority: development of } \\
\text { innovative infrastructure }\end{array}$ \\
\hline From 25 to 50 & $\begin{array}{l}\text { Cluster formed on the basis of } \\
\text { territorial production complex. } \\
\text { Priority: the formation of points } \\
\text { of growth in industrial } \\
\text { production }\end{array}$ & $\begin{array}{l}\text { Cluster with a clearly } \\
\text { defined core. } \\
\text { Priority: development of } \\
\text { innovative infrastructure }\end{array}$ & $\begin{array}{l}\text { Cluster with a developed } \\
\text { competitive environment. } \\
\text { Priority: development of } \\
\text { innovative infrastructure }\end{array}$ \\
\hline More than 50 & $\begin{array}{l}\text { A cluster formed on the basis of } \\
\text { territorial production complex. } \\
\text { Priority: the formation of points } \\
\text { of growth in industrial } \\
\text { production }\end{array}$ & $\begin{array}{l}\text { A cluster that has a clearly } \\
\text { defined core. } \\
\text { Priority: development of an } \\
\text { innovative cluster core }\end{array}$ & $\begin{array}{l}\text { Cluster with a developed } \\
\text { competitive environment. } \\
\text { Development of the institutional } \\
\text { environment of the cluster }\end{array}$ \\
\hline
\end{tabular}


The leading role of large-scale industrial production is characteristic for cluster strategies of the Republic of Tatarstan, the Republic of Bashkortostan, the Arkhangelsk and Nizhny Novgorod regions, and the Khabarovsk Territory. At the same time, cluster development is expected here due to a more intensive transfer of scientific and technical research results to the activities of existing industrial companies, as well as the creation of new small and medium-sized enterprises that are built into the value chains formed by large companies [16].

The development programs for clusters in Pushchino, Obninsk, Troitsk, Dimitrovgrad are characterized by an orientation toward using the potential of the worldclass scientific and educational organizations located on their territory. This involves attracting large Russian and foreign companies to the development of high-tech production due to the existing human resources and research infrastructure of clusters, as well as the active development of small and medium-sized innovative entrepreneurship through the commercialization of technologies developed here. Thus, the variety of models for the development of clusters determines the need to use the most flexible use of government support instruments, taking into account the specifics of each specific region [19].

The obtained parameters of the clustering model are based on the following data. According to the data of the Russian cluster observatory [17] from the clusters considered «Innovation Cluster of Information and Biopharmaceutical Technologies of the Novosibirsk Region» (60 organizations, 12,869 employees) and «Cluster of information technologies, radioelectronic and telecommunications of St. Petersburg» (66 organizations, $20838 \mathrm{em}-$ ployees) are at a high level of organization development. «Innovative territorial cluster of fiber-optic technologies "Photonics"» (34 organizations, 15762 employees), "Innovative territorial cluster "Zelenograd"» (48 organizations, 7772 employees), «Information Technology Cluster of Vologda Region» (31 organizations, $6182 \mathrm{em}-$ ployees) and Cluster "Energy Efficient Lighting and Intelligent lighting control systems" (24 organizations, 9,866 employees) are at the medium level of organizational development. Accordingly, the values of the Herfindahl-Hirschman Index and the Coefficient of Concentration for these clusters are presented above in Table 3.

The remaining clusters are located at the initial level of organizational development. The systematization of the findings is presented in the form of models of organizational development of clusters of microelectronics, instrumentation and information technologies in Table 5.

\section{CONCLUSIONS}

Analysis of the production localization processes allowed us to conclude that the high localization coefficient of production is a factor in the successful development of cluster initiatives. At the same time, it is necessary to emphasize that the localization of production is of funda- mental importance for the effectiveness of cluster policy both within the key sector for the cluster and within the framework of the enlarged type of activity and related types of industrial production.

This trend is because innovative clusters form the technological core of modernizing the economic space of the region as a whole. Clusters, acting primarily as a supplier of innovative technologies, new materials and means of production, and form an institutional environment for the transmission of successful management practices. Consequently, an additional criterion for differentiating clusters from territorial production complexes is the development of non-traditional types of economic activity for the region, targeting not only large enterprises, but also small and medium-sized forms of innovative entrepreneurship.

The identified directions of clustering economic systems of the Russian regions include nuclear and radiation technologies, medical industry, biopharmaceutical technologies, aircraft building and space industry, machine and equipment manufacturing, new materials, automotive and auto components.

The results proposed in the study can find application in the sphere of government policy of development the knowledge-driven economy. Thus, the proposed models were used by government authorities of the Republic of Mari El (Russia) while developing the programs for innovation development of the region's economy. The models of the formation and development of the innovative clusters considered in this article were used by the city administration of Yoshkar-Ola in the process of formation of a local natural resource-based innovation cluster in frames of collaboration between the Volga State University of Technology and government agencies of the Mari El Republic. The obtained results served as a basis for further research into modeling of regional industrial clusters, including spatial modeling based on geostatistics methods.

\section{ACKNOWLEDGMENTS}

This researchers was supported by the Grant of the President of the Russian Federation for the state support of young Russian scientists MK-1479.2017.6

\section{REFERENCES}

1. Achenbach Y.A., 2012. Modelling of the mechanism of interaction among the subjects of the regional economy based on the concept of formation and development of the scientific and industrial clusters. FES: Finance. Economy. Strategy, 11(62), 17-23.

2. Arthur B., 1989. Competing technologies, increasing returns, and lock-in by historical events. Economic Journal, 99, 116-131. 
3. Bergman E.M., Feser E.J., 1999. Industrial and Regional Clusters: Concepts and Comparative Applications. Regional Research Institute, WVU. http:URL:http://www.rri.wvu.edu/WebBook/Bergman-Feser/chapter3.htm Access on: 20.08.2017.

4. Boush, G.D., O.M. Kulikova, I.K. Shelkov, 2016. Agent modelling of cluster formation in regional economic system. The region's economy, 12, 64-77.

5. Dunford M., 2003. Theorising regional economic performance and the changing territorial division of labour. Forum de la régulation, Paris. http://web. upmf-grenoble.fr/regulation/Forum/Forum_2003/Forumpdf/RR_DUNFORD.pdf Access on: 20.08.2017.

6. Dzhindzholia A., E. Popkova and L. Shakhovskaya, 2015. Cluster as an Innovational and Organizational Form of State Regulation of Business. American Journal of Applied Sciences, 12, 814-819.

7. Feser E.J., 1998. Old and New Theories of Industry Clusters. Clusters and Regional Specialisation, ed. by M. Steiner. London, Pion Press.

8. Gubanova M, Bessonova E, Anoshina I., 2017. Investment climate as a factor of social and economic development in regions of the Russian Federation. Journal of Applied Engineering Science, 15(4), 455458.

9. Hopf C.G. and G.A. Tularam, 2014. A mathematical analysis of the inclusion of institutional betting funds into stock market: The case of technical and fundamental payoff models in horserace betting. Journal of Mathematics and Statistics, 10, 390-400.

10. Ketels Ch., Lindqvist, G. and Sölvell, Ö., 2012. Strengthening Clusters and Competitiveness in Europe. The Role of Cluster Organizations. Available at: http://gosbook.ru/node/84334 Access on: 20.08.2017.
11. Kleiner G.B., 2015. Strategic planning and enterprise development. Plenary presentations and materials of the Round Table. Fifteenth All-Russian symposium. Moscow, CEMI.

12. Matafonova Yu.A., 2016. Systematic Interpretation of the Factors of Federal Sustainability and Socio-Political Security of a Constituent State of a Federation. American Journal of Applied Sciences, 13, 222-229.

13. Pozdnyakov A., 2017. Ecological and economic aspects of planning of urban development. Journal of Applied Engineering Science,15(4), 418-421.

14. Porter, M., 2003. The economic performance of regions. Regional Studies. 37 (6/7), 549-578.

15. Regions of Russia Social and economic indicators, 2015. Statistical compilation. Moscow, Rosstat URL: http://www.gks.ru/wps/wcm/connect/rosstat_main/rosstat/ru/statistics/publications/catalog/ doc_1138623506156

16. Rukomoinikova V., Polukhina A., 2016. Development of cluster approach in tourism (Russia case study). Journal of Applied Engineering Science, 2016; 14(1), 61-67.

17. Russian cluster observatory. Available at: http:// cluster.hse.ru Access on: 20.08.2017.

18. Sölvell Ö., 2009. Clusters - Balancing Evolutionary and Constructive Forces. Stockholm, Ivory Tower Pub.

19. Tkacheva T., Afanasjeva L., 2017. Public-private partnership as an encouragement tool of innovative development. Journal of Applied Engineering Science, 15(3), 242-246. 